\title{
Entrepreneurial processes and the social construction of opportunity
}

\author{
Denise E. Fletcher, \\ University of Sheffield Management School, \\ 9 Mappin Street, \\ SHEFFIELD. UK
}

S1 4DT

\begin{abstract}
In contrast to structurally-determinist and cognitive/agency oriented views of opportunity recognition, it is argued that opportunity formation is relationally and communally constituted - an insight that is not recognised in descriptive or linear process models of opportunity recognition. To arrive at this claim, use is made of social constructionist ideas. These ideas have been frequently applied in entrepreneurship studies but less attention has been given to the relational aspects of social constructionist thinking particularly with regard to opportunity formation processes. To aid this line of inquiry an analysis is undertaken of a siblingautobiographical account of a high profile business venture, Coffee Republic. This account has been crafted by the sibling partnership with a particular audience in mind (the would-be entrepreneur) with guidelines and principles on how 'anyone can do it'. However, it is not utilised here as a good specimen of business venturing to be probed for particular (hidden) meanings. Instead, the account is evaluated in order to illustrate how individualistic statements about opportunity discovery can be reconceptualised as relationally and communally constituted - an emphasis which is important for widening our theoretical understanding of the activities we label entrepreneurship.
\end{abstract}

Key words: opportunity formation, social construction, relational processes, Coffee Republic, entrepreneurial processes. 


\section{Entrepreneurial processes and the social construction of opportunity}

\section{Introduction}

To open this article and frame the questions I want to discuss therein, I have two particular (and interrelated) considerations in mind. The first consideration is concerned with addressing, as one of the reviewers of the present article put it, 'something that is urgent' in entrepreneurship inquiry. The second relates to the utilisation and positioning of social constructionist ideas as a means of widening theoretical explanation of entrepreneurial practices.

My inclination would be to try to appeal to the reader directly with discussions on social constructionist ideas (and its various emphases and applications in entrepreneurship). But, I am aware that the very term 'social construction' is highly contentious and there is a danger that its use is as much likely to deter as it is to attract interest (given a tendency for social constructionism to be identified with idealism, relativism, linguistic reductionism and inability to account for the physical and material entities of the real world). And, there is also a tendency, particularly in entrepreneurship studies, for individuals (or certain types of people/personalities and agency) to be over-privileged for their role in social construction process.

To persuade the sceptical reader that social constructionist work is as much concerned with the 'real' world as a realist study would be, I could report a view from my study window where I watch with a 'birds-eye view' the construction of a two-storey extension on the end of the house. I can see, as Czarniawska-Joerges (1992:33) puts it, physical entities like bricks, mortar, machinery and equipment. There is human labour in the form of brick layers, labourers and the project manager etc. And there is architectural design and aesthetic expression as the client-customers enact their house/lifestyle vision in relation to the builder-adviser who is drawing upon his stock of construction knowledge about rural property development. There are also strict building regulations which dictate wall cavities, door openings, foundation depths, roof pitches etc - all of which have to be adhered to but are open to a small degree of negotiation/interpretation as the physical and material house entity takes shape. 
As Czarniawska-Joerges (1992:33) comments, each of these elements or aspects 'are socially constructed and put together by a socially constructed concept of [rural farmhouse] building'. The construction of both the physical features of the building entity and the concept of rural farmhouse building is multi-faceted, multi-dimensional and multi-voiced. Their construction is at the same time real, tangible, physical, material and cultural, social, political and institutional, shaped not only by the lifestyle requirements of the customers but also social changes in the countryside and legal/political/institutional facts such as property ownership and environmental protection.

There has been a frustrating tendency, however, for social constructionist ideas to be maligned and misappropriated. The ideas are sometimes maligned for their inability to say anything 'solid' about social reality (Alvesson and Skoldberg, 2000). The term 'social construction' is also misappropriated when it is used as a 'catch-all' label to categorise any research work that has a 'qualitative' orientation emphasising words, contexts, language, discourse and meaning-making. But social constructionist work is not merely concerned with linguistic representations, meaning-making and sensemaking processes at the individual or inter-personal level. As illustrated above, it derives theoretically from the relationality between people, institutions, material objects, physical entities and language, rather than the private sense-making activity of particular individuals. As a result, we are encouraged to see our modes of description, explanation and representation as derived from relationship.

In relating to these ideas in this article I do not intend to imply that social constructionist ideas are a panacea for all the things that are wrong in entrepreneurship (epistemological, ontological, theoretical etc). On the contrary, following Czarniawska (2003), I aim to promote a constructionist way of thinking about the activities we label entrepreneurship. At the same time, I illustrate how it is possible to undertake analysis of an entrepreneurial account from a constructionist perspective. In so doing, I not only aim to recognise and credit social constructionist thinking but also to encourage further dialogue on the application of these ideas to the study of entrepreneurial activities. To this I shall return shortly but beforehand I 
outline the second consideration underlying this article which takes us to 'something that is urgent' in entrepreneurship inquiry.

The second consideration relates to the paradox in the seeming ability for entrepreneurship as a topic or field of inquiry to have relevance and meaning to such a wide range of interest groups (newspapers, television producers, universities, students, academic staff, publishers and corporate managers), at the same time as lacking theoretical and scholarly development. Why is it that the activities usually associated with the term entrepreneurship can be pervasive and ever-present in different spheres of economic, political and social life and yet be simultaneously criticised for theoretical underdevelopment? This is even more surprising if we recall that entrepreneurial activities are not new to the twentieth century. Indeed, the practices we read about today in newspaper reports, documentary programmes and popular biographies are probably little different from the activities of the Venetian merchants of the ninth century or the industrial capitalists of the nineteenth in their search for new markets and opportunities. The activities might not always have been labelled with the term entrepreneurship but from even a cursory biographical reading of the key nineteen century industrial owner-managers, or families, communities, and regions of Europe, the behaviours and activities we would now define as entrepreneurial can be identified.

It is fair to claim, then, that there are a whole range of activities and practices going on in a variety of social, economic, political and family spheres that are (or might be) labelled with the term entrepreneurship. Some are critical of the seductive and pervasive societal discourses associated with the term '(du Gay, 1996; Nodoushani and Nodoushani, 1999; Ogbor, 2000). Others argue that this evidence reflects the natural, everyday and inherently intrinsic (creative) capabilities of human endeavour, implying that entrepreneurial activity is, in fact, a societal phenomena (Katz and Steyaert 2004). And it is this latter emphasis that provides a basis for the theoretical (i.e. ontological/epistemological) framing that is outlined in this article.

In what is to follow, I consider how people involved in new business venturing retrospectively report on the process of opportunity formation - a process that is commonly associated with the term entrepreneurship. However, in contrast to both 
structurally-determinist and cognitive/agency oriented views of opportunity recognition, I argue that the business venturing process is relationally and communally constituted - an argument which is not fully taken account of in descriptive or linear process models of opportunity recognition. I also consider how, when speaking about their business venturing experiences people are, to paraphrase Gergen (1999:49), 'reflecting on particular forms of understanding and in so doing not only fashioning their past (and future) but are also involved in sustaining forms of relationship that will enable particular traditions (and cultural practices) to remain sensible to both themselves and others'.

To develop this kind of an analysis, use can be made of constructionist ideas. In so doing, I respond to concerns about the lack of theoretical development within entrepreneurship inquiry - the reason for which has been attributed to a focus on phenomenological lines of inquiry (Ucbasaran et al., 2001), an over reliance on anecdotes or stories and a preponderance of positivist/functionalist paradigms (Grant and Perren, 2002) and the lack of sophistication of qualitiative methods (Olson, 1997; Sexton, 1997). But I argue here, supporting Shane and Venkataraman (2000) and Busenitz et al. (2003), that what is needed is closer consideration of the ontological/epistemological aspects of our research. This means careful examination of the meta-theoretical foundations of our research (Grant and Perren, 2002). It also means more extensive excursions into the philosophical issues that aid scholarly work and theoretical development (Busenitz et al., 2003).

Of course, it is appropriate to question why such an excursion into philosophical issues is necessary to understand entrepreneurship. Surely, as Curran and Blackburn (2001, p.53) argue, only a working knowledge of philosophical issues is needed for the accomplishment of competent entrepreneurship research? This point is a valid one and reference to issues of epistemology and ontology should be purposeful and helpful to the research investigation. But, at the same time, if engagement with the philosophical aspects of our research aids depth of analysis, robustness of research process or outcomes and contributes to the on-going theoretical development of entrepreneurship research, then this seems a useful way of going forward. And it is in this way that social constructionist ideas can be helpful. 
In section one of what is to follow, I take up the debate about processes of opportunity formation. In section two, I present segments from an autobiographical account of business venturing. I analyse this text in relation to general models of opportunity recognition. A brief background and overview of social constructionist thinking is provided in section three in which three emphases are outlined. In section four, I apply these ideas to aid analysis of an autobiographical account of the emergence of the Coffee Republic business. The article is concluded with a summary of how relational constructionist ideas contribute to both an understanding of opportunity formation and the theoretical development of entrepreneurship inquiry.

\section{Processes of opportunity recognition}

Following successive shifts and movements in entrepreneurship inquiry in which research attention has highlighted the traits, personalities, orientations, motivations, structures, policies, mechanisms, processes and cultures that shape entrepreneurial practice, there is now general accord that the process of opportunity discovery is distinctive or unique to entrepreneurship.

Studies investigate how opportunities are 'discovered', for example, at the individualopportunity nexus (Shane, 2003) in relation to peoples' special cognitive skills (Shane and Venkataraman, 2000; Baron, 2004), organisational learning processes (Lumpkin and Lichtensten, 2005), networking skills (Arenius and Clercq, 2005) or career choices (Lee and Venkataraman, 2006). It is not the intention here to provide a detailed review of the opportunity discovery view of entrepreneurship (see Casson, 2005). What is intended, however, is to highlight that these frameworks (including Shane, 2000; Shane \& Venkataraman, 2000; Lumpkin et al. 2003) collectively offer a range of concepts that characterise the opportunity recognition process (i.e. networks, experience, ideas sharing, prior knowledge of markets, entrepreneurial alertness). And the main aim of such models is to identify how (in varying degrees) these conceptual categories are central to the incubation, evaluation, recognition, discovery and formation of entrepreneurial opportunities.

The concepts provided in the opportunity discovery models are helpful for describing and mapping the new business emergence process. As will be illustrated shortly, in 
relation to Coffee Republic, all the various conceptual categories (such as experience, background, education, idea sharing, incubation etc) can be 'filled' with illustrations from most case material. The frameworks are also helpful for highlighting relationships between various practices (i.e. the relationship between prior knowledge of markets/ customer need and personal experiences; idea sharing and the role of personal networks). And these linkages or relationships are sometimes accounted for in process understandings of entrepreneurship (Gartner, 1990; 1993; Steyaert, 1998; Kupferberg, 1998; Gartner et al. 2003; Fletcher, 2003) and analyses that aim to link macro, micro, individual, firm, industry levels of analysis (Davidsson and Wiklund, 2001; Busenitz et al. 2003). Empirical studies applying process understandings of opportunity recognition are still quite rare, however.

Where the opportunity recognition frameworks are more limited is in their ability to account for why people enact opportunities in the way (and at the time) that they do in relation to broader societal, economic and political processes. This limitation arises for three reasons. The first relates to the assumption that opportunities, having been generated by certain market disequilibria, sit 'out there' in the market place waiting to be seen and realised by certain alert individuals. The second problem related to this is that too much agency tends to be attributed to individual people who make judgements about where there are gaps in the market on the basis of their market knowledge, perceptual abilities or special skills in 'seeing', identifying and selecting from a range of opportunities. And the third problem is that, beyond the inclusion of networks and personal background experiences, there is little attention to the wider societal, economic or cultural structures or patterns that shape entrepreneurial practice.

One explanation for this is that entrepreneurship research (following studies of organisations, more generally) has been strongly influenced by dualist and mostly determinist explanations of opportunity recognition. Explanatory mechanisms are drawn from points on a range of subjectivist-objectivist, realist-non-realist, deductiveinductive, voluntarist-environmental continua. And they are often located in paradigms that characterise particular assumptions about social reality (i.e. the radical structuralist, radical humanist, functionalist, interpretivist paradigms promoted by Burrell and Morgan, (1979) in organisation studies, and Grant and Perren (2002) in 
entrepreneurship. These categories of assumptions are helpful to the extent that they highlight the contrast and duality of various positions thus enabling researchers to surface their own assumptions about how particular organisational/entrepreneurial practices come to 'occur' or 'be' in the social world. The weakness of such frameworks, however, is that they encourage dualism and polarity, rather than interrelated understandings of how things are in the world. Also, such frameworks exacerbate, rather than resolve, concerns about coherence and fragmentation within a field of inquiry (both issues of which have received much attention in organisation studies (see Kelemen and Hassard, 2003) and entrepreneurship (Harrison and Leitch, 1996; Aldrich and Baker, 1997). In addition, being overly concerned with paradigm positioning, means that less consideration is given to the interrelationship between individual acts of entrepreneurial agency and the cultural, social and opportunity structural spatial environment in and through which such activities are recursively reproduced at specific points in time.

To address these limitations and provide for a wider understanding of opportunity formation processes, it is helpful to utilise social constructionist thinking. Social constructionist ideas sensitise us to a set of assumptions about social reality and the ways in which we relate to and construct understandings of that reality. Social constructionist ideas have a lot in common with structuration theory (Giddens, 1979; 1994) - a point which is also made by Bouchikhi (1993), Jack and Anderson (2002) and Goss (2005) in relation to entrepreneurship. But where structuration theory is concerned with the duality-of-structure (or, in entrepreneurship terms, the selection, modification and use of structure-guided scripts to effect entrepreneurial opportunity, Chiasson and Saunders, 2005), social construction work is more concerned with the representation systems (language, concepts, images, objects, social processes, relational processes) that are produced in explaining the duality of structure (Hall, 1997). It also takes, as its theoretical and practical point of departure, the whole of human relations and their social context, rather than the independent and private space of particular individuals. This aspect of social construction process is often marginalised or ignored, particularly in entrepreneurship inquiry. Before discussing this more fully, however, a short overview of ideas about social construction processes is presented to contexualise their application in entrepreneurship inquiry. 


\section{The social construction of reality: ideas and assumptions}

Ever since Berger and Luckmann (1966) coined the term 'social construction of reality' to emphasise the shared processes and negotiated understandings in which people engage to create meaning, there has been potential for the application of these ideas in the study of business and management. Application of these ideas for research purposes, however, is not a straightforward task. Many researchers utilising qualitative methods use the social constructionist label to define or position their work even though they are more concerned with the subjective experiences and perceptions of their respondents rather than the ways in which meanings are negotiated/shared through social processes contributing to the social construction of reality. So indeterminacy escalates as writers debate what it is that is being socially constructed (Hacking, 1999) whether this be time (Fischer et al. 1997), meanings, identities, 'lived experiences' (Bruner, 1990; Denzin, 1997), the self (Gergen, 1999) or social reality (Berger and Luckmann, 1966). As a result, ideas about social construction are often misunderstood (for their linguistic reductionism, for example) and maligned (for their ability to be able to say another "solid” about social reality, for example).

In addition, different terms such as constructivism or constructionism are often used interchangeably. Sometimes the terms are prefixed with 'social'. At other times, they are not. Also, a variety of emphases and variants can be identified (such as cognitive constructivism, social constructivism or constructionism and relational constructionism). This variety is due to the fact that social constructionist ideas have their roots in many intellectual traditions including symbolic interactionism with its interest in subjective meaning (Mead, 1934; Blumer, 1969; Goffman, 1972) and social phenomenology (Schutz, 1967) where conscious experience is derived from social interaction. It is not the intention here, however, to trace the philosophical roots of social constructionist ideas. What is important is to stress that the variety of roots explains the range of explanatory structures focused on in the study of social construction. Some examples of this variety are outlined now in relation to entrepreneurship studies. However, it is important to note that these emphases are not necessarily expressed in this way in other subject areas. 
Social constructivism, however, following Vygotsky, (1962) and Bruner, (1990) is more concerned with how individuals mentally construct their worlds with categories supplied by social relationship (Gergen, 1999). So, the key interest is individual cognitive processing but equal attention is also given to the socio-cultural practices or norms that shape this ${ }^{1}$. In entrepreneurship studies, social constructivist analyses are concerned with how cognitive processes are mediated through social situatedness and cultural or discursive practices enabling entrepreneurial behaviour and opportunities (Chell, 2000; Anderson, 2000), life scripts (Pitt, 1998) and stories (Dodd, 2002; Rae, 2002).

In social constructionist efforts (drawing primarily upon Berger and Luckmann, 1966 and Giddens, 1984) there is a closer examination of the interplay between agency and structure linking individual constructions of sense-making and enactment to the societal level through processes of structuration (Bouchiki, 1993; Zafirovski, 1999; Bruyat and Julien, 2001; Goss, 2005). Within this emphasis, some promote the 'embeddedness' of entrepreneurial practices (Zafirovski, 1999; Jack and Anderson, 2002). Other commentators highlight the situated, community or local cultural and historical context as the medium for social construction process (Hjorth and Johannisson, 2003). And other inquirers examine entrepreneurial emergence and enactment (Gartner et al., 2003) through auto-ethnography (Johannisson, 2002) and narrative or storying processes (Bouwen and Steyaert, 1997; O’Connor, 2002; Rae and Carswell, 2001; Downing, 2005; Fletcher 2007).

Finally, there is a further emphasis that might be called relational constructionism. Here, relating to ideas from the sociology of knowledge (Berger and Luckmann, 1966; Weber, 1978; Durkheim, 1982), social phenomenology (Schutz, 1967) and cultural psychology (Gergen and Gergen, 1991; 1999) inquirers give more emphasis to the relationality and co-ordinations between people and their text/contexts (Bouwen and Steyaert, 1990; Dachler and Hosking, 1995; Bouwen, 2001). In entrepreneurship, some give more emphasis to individuals as 'relational beings', who, in relation to past and future interactions/relations engage in acts of becoming as they create new

\footnotetext{
${ }^{1}$ In entrepreneurship research, however, although many researchers adopt a cognitivist orientation (Manimala, 1992; Hill and Levenhagen, 1995; Baron, 1998; Busenitz and Barney, 1997; Shane and Venkataraman, 2000) they are not necessarily constructivist in philosophical orientation.
} 
possibilities (Bouwen and Steyaert, 1990; Fletcher and Watson, 2005). And others draw attention to the generative discourses and relational processes signifying and performing the material and social world (Hosking and Hjorth 2005).

I will return to a fuller discussion of the contribution of social constructionist thinking in the final part of this article. Before this, however, it is helpful to consider these ideas in relation to a particular account of business venturing.

\section{'Anyone can do it': building Coffee Republic from our kitchen table, by Sahar and Bobby Hashemi}

The extract below is taken from the book 'Anyone can do it' (Hashemi and Hashemi, 2002) in which co-founder/owner Sahar Hashemi speaks about building of the Coffee Republic business with her brother. The following segments are taken from the first two chapters of the book (pps. 15-24) which are concerned with whether 'anyone can be an entrepreneur' and the process through which the business idea emerged. Due to word limitations, certain sentences have been reduced (these deletions are highlighted in the text). However, care has been taken to retain the flow of the story as recounted by Sahar Hashemi. The book contains subsequent chapters on 'market research', 'writing the business plan', 'raising money for your idea', 'implementation', 'being in business' and 'growing' the business. The aim of the book is to inspire people that do not consider themselves as entrepreneurial to venture forth with their businesses ideas. They propose 57 'real life laws' on how a successful business venture can be realised. Sahar and Bobby Hashemi had to visit 19 banks with their business plan to raise the \$165,000 needed to create a New York-style coffee bar in London. In 1996 they had one store in London. In six years they increased to 90 stores in the UK with a turnover of \$16 million. They became a public limited company in 1998 and in 2001 sold the business - although Bobby Hashemi has since returned as Chairman.

\section{'Our story - how we got there' (pages 15-24)}

'We are siblings. There are four years in age between us, with Bobby being the older. Entrepreneurship wasn't in our genes. We don't come from a family of entrepreneurs. Our father was a corporate executive. Our mother was a full-time devoted mother. We have no 
connection whatsoever with retail, food brands or coffee in any shape or form. If anything, we are quite the reverse of the apocryphal entrepreneur who dropped out of school but whose genius could nevertheless not be constrained. We followed the path of education according to convention and instead of learning the laws of supply and demand by trading in the school playground, we spent the time playing instead. We were frighteningly average people. We were in no way exceptional. Neither of us were overachievers or under-achievers either at school or in our hobbies. We didn't necessarily stand out as having amazing talents or particular brilliance in anything requiring us to use our imagination. Creative is something we were not. Not only were we not brought up to be entrepreneurs, we were taught to study 'useful subjects' and aim for a solid profession. So Bobby studied computer engineering and Sahar studied law. If we got any training for entrepreneurship in our upbringing, then it was being taught the value of discipline and hard work. We were taught that the key to success was not a matter of inspiration but rather 'it's all about perspiration'. What you put into something determines what you get out. Our parents' maxim was 'it's not about being the best' but doing your best'. They believed that if you put your head down, worked hard and persisted, you could achieve anything. That is the most important lesson we were ever taught.

At the same time as Bobby was working in New York, Sahar was a lawyer at the prestigious law firm of Frere Cholmeley in Lincoln's Inn Fields, London. [... ] Sahar's stint in the corridors of law corresponded with a golden period of big deals, power suits and the inexorable rise of he glamorous female lawyer...... But after qualifying as a lawyer though, everything started to change [....] Being a lawyer was very different from being a trainee lawyer. The meetings, the fun and the glamour came to an abrupt end. [....] Rapidly she decided that this was not the life for her... Her intuition was telling her that she not happy as a lawyer - but she didn't want to listen to her negative inner voice, especially after so much hard work (to become a lawyer).

Then suddenly everything changed...

In a moment, both our worlds were turned upside down. A life changing moment. On the night of $23^{\text {rd }}$ January 1993 our close-knit family of four was shattered with the sudden death of our father from a stroke at the age of sixty-two [....]Our father's death was a paradigm shift for both of us. It was the sort of event that shakes up every single supposition or plan you've ever made - the sort of shock that sees you putting on new lenses and looking at the world in a totally different light, where nothing that came before matters in the slightest way. The loss of a parent strips you from your comfort zone, making other drastic changes you once considered too risky much easier too undertake. 
[....]By the end of 1994 what we both didn't realise was that we had subconsciously made the big break from our comfort zones. We had cut the umbilical cord. Although we spent 1993 in a bit of a daze [....] by the end of 1994 we were fairly restored. Our time off also gave us time to clarify what we wanted out of life and our careers. Little did we know that by leaving the comfort zone and really thinking about our personal and career goals we had taken the first step in the journey of entrepreneurship. The truth is that we never thought for a moment that we would end up working together, let a lone starting a business together.

Bobby had decided not to go back to Lehman [....] and was looking at options for starting his own business. So we were both floating in the middle of a somewhat broad ocean, neither possessed of any particular direction and with no sign of shore in sight.

\section{Our story: how we got the Idea (p.31-34)}

On the night of 4 November 1994, [....] feeling utterly despondent [....] Sahar went to an evening seminar given by a firm of legal headhunters [....]Bobby had agreed to collect her afterwards to go out for a Thai meal [....] with our mother. Sahar got into the car feeling totally deflated but $[\ldots .$.$] she could sense an overpoweringly positive energy from Bobby.$ Bobby was beaming with a business idea. Or, in the Zen sense, the Idea had taken hold of him. He was totally engaged in the process of developing the Idea in his mind, though Sahar didn’t even know what it was.

Basically, on her way back from [a trip to Argentina], Sahar had stopped in New York for a couple of weeks and being an early riser she had become used to going to a coffee bar called New World Coffee on Madison and $44^{\text {th }}$ Street.

There she experienced for the first time a speciality coffee bar with its skinny cappuccinos (a real novelty at the time) and fat-free carrot muffins (also previously unknown) and everything else that made the experience seem like a haven of luxury in the hustle and bustle of the day.

When Sahar returned from New York, she raved on to Bobby about how totally in love she was with these incredible coffee bars $[\ldots .$.$] and how much she missed them [....] and how$ much she wished they had the same thing in London. As Sahar was enthusing on the subject, somewhere in the back of his mind Bobby remembered that [during his job at Lehman the enormous coffee drinking boom in the USA was brought to his attention]. Then, with these thoughts logged somewhere in the recesses of his subconscious, on that very day he had been 
out to several meetings and had been shocked to realise that you could not stop off for an even half decent cup of coffee anywhere in London. Bobby couldn't help but think back to what Sahar had said. She was right!

So Bobby got the Idea. The light bulb in his head turned itself on and the first step on the road to entrepreneurship was almost subconsciously taken. He was determined that he and Sahar should start up a chain of US-style coffee bars in London. Sahar protested vehemently about any involvement from her. [....] Bobby, however, managed to persuade her that he would pay her to do the research for one week only and added that it would be her decision whether to move the ideas ahead or not. [.... ] She agreed to Bobby's proposal.

Sahar goes on to recall how she set of the following morning into High Street Kensington circumnavigating the Circle Line getting off at every single one of the 27 stops. [....]. She comments how she 'loved what she saw. There was obviously a huge demand for coffee, though the product itself was horrible' indicated by the queues at sandwich bars for coffee. However, she comments that 'the product being served was essentially brown sludge in a grubby polystyrene cup [....]'. It occurred to her that the reason the coffee was so poor was because all the outlets she visited were essentially focused on other products [....]

She continues her recollection: 'she could not believe how strongly she felt that day, and she realised that there was an enormous gap in the market for a high-quality coffee experience where the main focus was on the quality of your coffee drink and not on anything else. So a light bulb also turned on for Sahar. London was missing out on a New York-style coffee experience and we could significantly enhance the quality of London's caffeine habit if we provided it. In terms of buying into Bobby's idea, that was pretty much that. Sahar was in, and that was the minute that Coffee Republic was born'.

\section{Using and analysing an 'off the shelf' entrepreneurial account}

This entrepreneurial account has been selected for a number of reasons. First, the Coffee Republic story is in the public domain and because the main product concept centres on coffee, it is accessible to many people and has relevance to a variety of audiences (consultants, bankers, students, researchers, consumers of coffee and would-be entrepreneurs). Second, the account is a high profile success story and is typical of the success stories that we read about in the popular press. Third, the business was built by a sibling partnership and written accounts of such partnerships 
are rare. Fourth, the book gives readers a thorough overview of the emergence of the business from the conception of the business idea to its realisation.

This is not an account, however, that has been derived from traditional interpretive research work as seen in ethnomethodology, criminology and ethnography. The account is not being presented as one that has been sought out through field work interactions in which that which is secret, sub-textual, taken for granted or hidden from usual sight is brought into the open. Nor, does the account hold, in its realisation and making, the tools (concepts, questioning) and 'presence' of the researcher-inquirer who would normally interpret and synthesise the account for presentation. Indeed, in the present case, the researcher is absent from both the building of the Coffee business and the construction of the retrospective account. But this does not imply that I am treating the account in an ontologically objective sense. By this, it is meant bestowing the account with entities, properties and social construction processes relating to entrepreneurship that anyone, regardless of gender, ethnicity and methodology, can 'pick out' from the text. But neither, to address those that are critical of the anecdotal/story-telling inclination of entrepreneurs, is this an account that merely privileges the subjective views and ways of knowing or opinions of one person.

In selecting this case study, I acknowledge that this is an account (meant here in the general sense of a narration or description) that has been artfully crafted with a particular audience in mind (the would-be entrepreneur). It has probably been told and re-told several times over (to both public and private audiences). Indeed, Sahar has presented this story at several events and conferences subsequent to the publication of the book. The point to be made, however, is that because this account is in the public domain it has become institutionalised as a 'social text'. Its authority as an account, therefore, lies not in its ability to reflect the 'truth' about what really happened' as recalled by the author and observed by the researcher. Neither does it gain credibility for its richness in 'embodying' specific meanings. The account's authority lies in its openness and ability to have relevance and meaning for a variety of audiences. 
An example of this authority is that people would choose to 'read' this account in the same way that one would look at a painting or a piece of sculpture. They might not necessarily know what the author's intentions were (beyond being told that Bobby and Sahar were keen to inspire others to do what they had done) but the meaning of the account/text is what it signifies to the reader/observer. The readers of the 'Anyone can do it' book might have their own experiences and interpretations of the Coffee Republic, possibly drinking coffee in one of their outlets, reading newspaper articles about Sahar/Bobby Hashemi and the business and/or seeing public presentations of how they achieved their business. In reading their book, some people might be persuaded to realise their business ideas. Or, they might decide business venturing is not for them. In any case, the authority of accounts such as these stems not only from the relatedness, associations and carry-over effects that they generate but also (in the case of this story) what this enables us to say about opportunity formation processes and how entrepreneurship 'goes on' in society.

For me, as an entrepreneurship tutor, my relatedness to the Coffee Republic account is expressed in what you are reading now - the application of social constructionist ideas to aid understanding about how opportunity recognition and enactment occurs. But, in relating to social constructionist ideas, the account ceases to be, as in traditional case study work, a specimen of business venturing to be probed for particular (hidden) meanings. Instead, it is more appropriate to refer to the account as a 'text' in which the inquirer can connect to the original words of an author/document, not in order to check the accuracy of some past occurrence but in order to help shape their thinking or practice in the future. Indeed, Knights and Willmott (1999) utilise four novels as 'literary case studies' to 'bring to life' various dimensions of managerial life. And it is in this sense that I utilise the Coffee Republic text. So that, when reflecting on particular forms of understanding (business venturing), Sahar and Bobby are, to once again use Gergen's words (1999:49), not only fashioning their past (and future), but they are also involved in sustaining forms of relationship (of consumption, family, culture and society). In so doing, they enable particular traditions and (we might say entrepreneurial) cultural practices to remain sensible to themselves and others. 
This will be illustrated most significantly in the discussion on relational constructionism which follows later. However, to give clarity to the distinctive notion of relational constructionism, it is important to recognise that there are other emphases of social constructionist thinking which might also be applied here. I will now explain and apply these emphases ('social constructivist' and social constructionist) in order to show what is distinctive about relational constructionism.

\section{i. A social constructivist reading of the Coffee Republic account}

A social constructivist analysis privileges individual, subjective knowing. With this emphasis, research attention focuses on Sahar and Bobby as the individuals at the centre of new venture creation. Particular linguistic expressions would be identified as representations of Bobby and Sahar's inner states (such as 'being in the idea', 'entrepreneurship as a journey', 'comfort zones' or 'paradigm shifts'). And understandings of entrepreneurship would be seen as being constructed through cognitive capabilities in the separate minds of these two people. In the Coffee Republic account, this is indeed the way in which Sahar and Bobby are constructing their account. As commented earlier, attention is initially drawn to the thoughts and cognitive processing of Sahar and how 'totally in love she was with these incredible coffee bars ... and how much she missed them'. Then she comments how the Idea first came from her experience of going around London and tasting the 'grubby', 'horrible', 'sludge' of existing coffee product offerings that she found from her research in London which encouraged her to think how she could offer a product which was superior, more attractive and more in line with what the 'young professional in need of an early morning cappuccino’ really wanted. But then a report is given as to how this unmet consumer demand was laying 'somewhere in the recesses of Bobby's subconscious' so that when he was at the point of looking to create a business, the idea began to take shape for him and bear significance - 'he was totally engaged in the process of developing the Idea in his mind'. In fact, reference is made to a zen notion of how the idea 'took hold' of Bobby. But then attention shifts back to Sahar and she protested 'vehemently' against the idea. As she walks around the streets surrounding the Circle line, Sahar recalls her cognitive processing as she moves from initial reluctance to 'being in the Idea.. 
Also, from a social constructivist perspective, consideration would be given to the social context and environment within which entrepreneurial activities are being constructed. Here, reference and linkages are made to the educational and family background of the entrepreneurs as a way of understanding and explaining the cognitive constructions of new business venturing. This occurs, for example, when Sahar comments on the 'life changing moment' and 'paradigm shift' that occurred when their father died and how this 'stripped them from their comfort zone' encouraging them to reassess their lives and move into the world of enterprise and entrepreneurship. But, from a constructivist perspective, these linguistic expressions would be seen as the external expression of internal cognitive processes.

\section{ii. A social constructionist reading of the Coffee Republic account}

In line with a constructivist emphasis, social constructionist ideas centre on individuals as social beings but attention is given to the social/cultural situatedness of particular practices and the interrelationship between agency and structure in the shaping of these practice (rather than cognitive aspects). This might be done by examining entrepreneurial lives/identities (Warren, 2004) or the various cultural, social, regional and community contexts (Johannisson, 1990; Hjorth and Johannisson, 2003) in which entrepreneurial practices are 'embedded' of (Zafirovski, 1999; Jack and Anderson, 2002).

To apply this to the Coffee Republic account, inquirers might examine the ways in which the emergence of the business (or the idea) was 'embedded'. in the sense of being located in particular social, cultural, economic contexts. For example, as discussed earlier, in constructing their account, Sahar and Bobby are relating directly to their family background ('mother as a full-time devoted mum', 'father a corporate executive') and lives as children 'playing' instead of 'trading in the playground'. They refer to their parents attitudes to education and work. Reference is also made to life in New York and high-flying jobs at Lehman or Frere Cholmeley - the successes and disillusionment. Analysis would, therefore, focus on issues related to biography, class, gender, culture, community and identity in order to identify how these are constituted in particular practices or peoples' lives. Such efforts are helpful for examining the cultural situatedness of entrepreneurial activities - a point which is also 
emphasised in anthropological reports of enterprise (Stewart, 1991). However, in utilising the language of 'embeddedness' entrepreneurial insights are limited to describing the socio- cultural context in and through which particular practices are situated/produced (focusing on structure-agency dualities), rather than explaining the relatedness between the physical objects, ideas, images, people, discourses and practices that constitute social reality.

Also, in examining how social reality is produced through the inter-subjective aspects of exchange does not mean, however, that social construction processes are only occurring at the inter-personal level. Of course, this is where our research is often directed whether through questionnaire, interviews, focus groups or other research methods. But when constructing a sense of ourselves, our lives, work and identities, we are also relating to the culture and society of which we are a part. This is because rules and resources are transmitted from our culture through media, education, family and peer influences acting as 'structural properties' shaping how we make sense of things and how we act in social settings. Thus, when speaking about the emergence of a business, the accounts entrepreneurs give are also an expression of relationship to the culture, society and the institutions (of capitalism, family, market economy, enterprise discourse) in which they have been reproduced. This expression of relationship to culture, society, economics and politics (and the rules and resources they transmit) is illustrated in the Coffee Republic account on a number of levels which are discussed below in no particular order.

\section{iii. A relational constructionist reading of the Coffee Republic account}

Although the business opportunity and 'light bulb’ moment is spoken of as being in the mind of Bobby first and then Sahar, this does not necessarily mean that opportunity formation is an activity that occurs primarily through, and because of, the special cognitive processing capabilities of these individuals as is implied in opportunity discovery models (op. cits.). When speaking about the emergence of business ideas, people tend to speak as if this sense-making process is occurring 'in the mind' or 'inside' the person (i.e. 'negative inner voice', overpoweringly positive energy' and Bobby 'beaming with a business idea'). But with relational constructionist ideas in mind, it is possible to argue that the creation of the business 
idea is as much a relational one in which the entrepreneurs are constantly relating to things around them (Bouwen, 2001).

For example, in constructing their account, Sahar and Bobby are constantly bringing to their thinking and dialogue previous understandings, experiences, inter-woven conversations and a history of relationships that are culturally, socially and politically situated. Although the opportunity emergence process is spoken of as occurring in the mind of Bobby and then Sahar, this process is in fact a relational one that has already been shaped by multiple conversations, dialogues and relational experiences. Building a business and identifying a market opportunity is, then, a relational activity characterised by multiple acts and supplements. Just as the act of offering one's hand to another as a gesture of welcome can be supplemented in many ways (Gergen, 1999; Hosking and Bass, 2001), so can the emergence of a business idea. The idea emerges through pieces of dialogue that are themselves fragments of previous conversations, experiences, thoughts and happenings. Ideas are always related to some previous understanding or experience, whether this be in relation to perceived gaps in consumer demand or in relation to peoples' own skills and knowledge (or not, as in the case of Sahar and Bobby where they knew very little about coffee or retailing). Also, the act of creating the business ideas is supplemented in a variety of ways. Ideas have to be cautiously tested out on trusted friends and potential customers. Spouses or family members have to supplement with capital, labour or emotional resources. The bank manager may supplement or not with a business loan. Supplier firms assess of the seriousness of the entrepreneurs to pay. In short, as the business is enacted it is supplemented and modified in many different ways through a variety of economic and social co ordinations. So, whether the account of entrepreneurial activities being given is one from spouses, siblings, mother-son or an individual entrepreneur, the act of realising a business idea is always relational. It always connects to something else that is going on, has gone before or will come again in the future. In this sense, it is possible to argue that the accounts people construct about opportunity emergence are expressions of relationship to the culture, society and the institutions (of capitalism, family, market economy, enterprise discourse) in which they have been reproduced. 
In this article, this expression of relationship to culture and society is analysed from three aspects: family processes, enterprise discourses and changing consumption patterns. First, let's consider the way in which Sahar relates to their family background. An account is given from which the reader can get a sense of the fairly affluent, middle class family background in which the siblings were brought up. Reference is made to aspirational educational values associated with middle class families ('to study useful subjects and aim for a solid profession') from which particular work ethic values (the value of discipline and hard work) were drawn. As well as the family background, the emergence of the business idea is set against previous high-powered careers in law and investment banking during the 1980's in cosmopolitan London and New York. For Sahar, enthusiasm for the entrepreneurial venture comes about after the 'glory days of big deals, power suits and... rise of the glamorous female lawyer (p.19)' began to wane. And, for Bobby, when the excitement of shuffling high-powered deals, big bonuses and all night working lost out to the dream of becoming an entrepreneur. So their account is set within an economic context of high-flying, high-paying corporate life in the 1980’s.

In addition, one might also consider the ways in which, when giving their account, Sahar and Bobby are also relating to broader political discourses relating to enterprise culture and entrepreneurialism. Much emphasis is made in the account of how 'entrepreneurship was not in our genes', 'we don't come from a family of entrepreneurs', 'we are quite the reverse of the apocryphal entrepreneur who dropped out of school', 'we were frighteningly average people', 'creative is something we were not' (p. 15-16). Indeed the title of the book is 'Anyone Can Do It'. In making these statements, the writers are referring to their culture and society in which media accounts and entrepreneurial biographies often eulogise those people associated with enterprise creation the constant reproduction of which can lead to the impression that only special people can do entrepreneurial things. So they are drawing upon and relating to resources or structural properties in their environment and culture. But also, in making claims about their ordinariness, they are criticising and challenging the dominant political discourses that prevail in Western society about heroic entrepreneurial figures in the hope of persuading others that 'anyone can do it'. 
Furthermore, there is also a spatial dimension to the way in which the emergence of the business opportunity is spoken of. This is partly taken account of when we speak about relationality to the culture or society of which we are a part. But cultural and social practices, ideas or images don't 'stay' in one place, they travel and migrate across boundaries. And, as they do so they sometimes bring about change or transformation. For example, in the account, Sahar relates to two city locations and cosmopolitan social, cultural and economic contexts - New York with its coffee bars, skinny cappuccinos, fat free muffins and London with its (then) 'sludgy grubby coffee'. Although the Coffee Republic venture is physically located in the UK, the idea about coffee consumption and the availability of fat free muffins has, to refer to Czarniawska and Sevon (1996), migrated or travelled across the world from a 'satiated' (U.S.) to 'non-satiated' (UK) context.

The consumption of fat free muffins and wide choice of coffee blends/types was taken for granted and widely available in the U.S. and these consumption patterns affected Sahar when she worked in New York and took her daily morning cappuccino - a pattern she chose to 'buy in' to because the morning cappuccino experience was 'a haven of luxury in the hustle and bustle of everyday life'. In this sense, she became satiated in a consumption process which was cultural, social (cosmopolitan New York, corporate lawyer) and aesthetic (in the sense of pleasing, comforting or energising the body, its senses and emotions) to the point that Sahar speaks of being 'totally in love' with her morning coffee.

On returning to the UK, this aesthetic and cultural knowledge or experience 'stayed' with Sahar as she encountered the product offerings in the UK. Through dialogue and interaction with her brother and through market research etc., this knowledge became ‘translated' into new contexts and activities (Czarniawska and Joerges, 1996). This is because business ideas and the assessment of what is a good business opportunity takes on a particular meaning or significance in a particular cultural, economic, historical or social context at a particular point in time. Hjorth and Johannisson (2003, p.80) refer to this as 'articulation' - that is, 'putting things out there of what might be' and gathering dispersed bits of information in order to relate past, present and future in ways that seem unrelatable but which help to reduce ambiguity and suggest a sense of order and a new way of becoming. This process 
was enhanced by their life/career reassessments at that point in time and the shedding of family/educational values that had been so much a part of their past lives and upbringing but the reassessment of which meant they could 'pave the way' for new activities and realities.

Finally, when speaking about the emergence of their business idea, Bobby and Sahar are reflecting on particular forms of understanding that have characterised their business venturing experience. In so doing, they are not only fashioning their past (and future) but they are also involved in sustaining forms of relationship to the culture, society and institutions in which they are located as they theorise and enact their business idea. They also enable particular cultural practices (i.e. coffee consumption) to transfer from one society to another. In producing their text, they are also stimulating further demand and creating new possibilities for those of us who read and engage with the ideas therein. And from these multiple connections to the ideas and understandings in their book, multiple patterns of social relations, meanings and understandings travel, thus contributing, over time, to the construction of social reality.

\section{Conclusion: entrepreneurial processes and the social construction of opportunity formation}

In many respects, both the practice and inquiry of entrepreneurship has come a long way. As evidenced in the monitoring and review efforts that have begun to feature in entrepreneurship inquiry (Journal of Business Venturing, 1999; Entrepreneurship Theory and Practice, 2001, 2005; Journal of Management, 2003; Steyaert and Hjorth, 2003), entrepreneurship inquiry has made significant progress in identifying a range of explanatory structures for understanding how and why entrepreneurial activities 'come about'. We have come far in identifying many different forms and definitions of entrepreneurial practice. Different levels of analysis are used from economies to regions, industries, groups of people, teams or individuals. And various aspects are measured, from macro environmental structures, cultures or government policies to the personality attributes of people. Also, entrepreneurship courses feature in all business school programmes. Newspapers give daily accounts of successful 
businesses and publishers commission text books, journals and biographies of the lives of entrepreneurial people.

It is fair to say, then, that entrepreneurship is hardly a newly emerging field suffering from immaturity, adolescence and the 'liability of newness'. But when it comes to understanding the process of opportunity recognition, beyond descriptive mapping or linear process models, understandings of how and why business ideas 'locate' with particular individuals at particular points in time are still fairly underdeveloped. For this reason, a review of social constructionist thinking has been undertaken in this article with specific attention to entrepreneurship (opportunity formation).

Being informed by a social constructionist sensitivity stimulates entrepreneurship inquirers to step out of the everyday busy-ness' of [their] lives to reflect upon how [they] are producing the field (Steyaert and Hjorth, 2003: 3-4). And research endeavours and their preoccupations with identifying the many forms, definitions, structures, processes and varieties of entrepreneurial practice become provoked to consider the purpose and process of entrepreneurship inquiry - particularly its epistemological/ontological assumptions - an issue identified by Shane and Venkataraman, (2000) and Busenitz et al., (2003) as central to scholarly effort and important for legitimacy of the field. This does not mean, however, that social constructionist ideas can be regarded as the only means of making transparent the epistemological/ontological foundations of our research. One might, for example, turn to critical realism, or post-structuralist ideas for alternative ways of discussing these concerns.

In a more specific sense, social constructionist ideas provide a theory of knowledge about the becomingness of social reality. These ideas provide the opportunity to work with a non-dualist epistemology and ontology focusing on relationaties rather than a division between objectivity and subjectivity. With a focus on relationality, social constructionist ideas move us beyond determinist understandings of social behaviour/practice. They also move us from over-privileging agency and its singular role in social construction processes. This is because their theoretical starting point is the whole of human relations and their social context, rather than the individual and private space of particular individuals. And we are encouraged to see our modes of 
description, explanation and representation as derived from relationship. People, structures, the physical world, culture, language, words, concepts, images gain their meaning from relatedness to each other and not to representations of how the world 'really is' or to the meanings that inhere in peoples' minds. Instead, meaning-making is relational and communally constituted. And our research becomes concerned with 'how things go on' and come about as a result of relational processes, rather than 'what is' (Dachler et al., 1995).

In terms of entrepreneurship, ideas about processes of social construction (with its various constructivist, constructionist and relational emphases) take us further than other approaches in accounting for 'what goes on' as people relate to various mental models, heuristics, life experiences, biographies and knowledge of (or gaps in) particular consumer patterns to enact business opportunities. But, utilsing social constructionist ideas means that the inquirer moves beyond an examination of individual opportunity seeking processes to consideration of the relationality between peoples' actions and their cultural, societal, economic and political situational context. This enables a distinctive theoretical understanding of opportunity emergence as relationally and communally constituted. It also challenges linear, individualistic and descriptive models of opportunity discovery. Further, it helps to account for the spatial aspects of opportunity recognition and the ways in which cultural/social practices travel and migrate thereby contributing not only to the construction of social reality but also the formation of new opportunities in new contexts. As the business owner of a new small, high quality coffee shop in a small market town in the U.K. commented to the present author:

'the good thing about these large coffee chains is that they have created a mass market of discerning coffee drinkers, but the problem with them is that they don't know how to make really good coffee and they certainly don't blend into the local environment. This is something we want to do with our coffee shops and we think there is a demand for this'.

This is the 'unfinished discursiveness' (Bourriaud, 2002) of entrepreneurship. The activities we label entrepreneurship require immense effort, negotiation and dialogue and they always 'go on' in relation to something else that has gone before. Herein 
lies the theoretical potency of the activities we label entrepreneurship. And here, too, social constructionist thinking offers scope for further dialogue. 


\section{References}

Aldrich, H. E. and Baker, T. 1997 Blinded by the cites? Has there been progress in entrepreneurship research? in D. L. Sexton \& R. W. Smilor (eds.), Entrepreneurship 2000 (Chicago, Ill: Upstart: pp. 377-401).

Alvesson, M. and Skoldberg, K. 2000 Reflexive Methodology: New Vistas for Qualitative Research. London: Sage.

Arenius, Pia, and de Clercq, D. 2005 A network-based approach on opportunity recognition, Small Business Economics, 24(3):249-265.

Baron, R.A. 1998 Cognitive mechanisms in entrepreneurship: why and when entrepreneurs think differently than other people, Journal of Business Venturing, 13(4): 275-294.

Baron, R.A. 2004 Opportunity recognition: a cognitive perspective, Academy of Management Proceedings, pp.1-6.

Berger, P. and Luckmann, T. 1967 The social construction of reality (New York: Anchor Books).

Blumer, H. 1969 Symbolic interactionism: perspective and method (Berkeley: University of California Press).

Bouchikhi, H. 1993 A constructivist framework for understanding entrepreneurship performance, Organisation Studies, 14(4): 549-570.

Bouwen, R. 2001 Developing relational practices for knowledge intensive organisational contexts, Career Development International 6(7): 361-369.

Bouwen, R. and Steyeart, C. 1990 Construing organisational texture in young entrepreneurial firms, Journal of Management Studies, 29(6): 637-649.

Bruner, J. 1990 Acts of Meaning (Cambridge, MA: Harvard University Press).

Bruyat, C. and Julien, P.A. 2001 Defining the field of research in entrepreneurship, Journal of Business Venturing, 16(2): 165-180.

Burrell, G. and Morgan, G. 1979 Sociological paradigms and organisational analysis: elements of the sociology of corporate life (London: Heinemann Educational).

Busenitz, L.W. and Barney, J.B. 1997 Differences between entrepreneurs and managers in large organizations: biases and heuristics in strategic decision-making, Journal of Business Venturing, 12(1): 9-30.

Busenitz, L.W., West, G.P., Shepherd, D., Nelson, T., Chandler, G.N. and Zacharakis, A. 2003 Entrepreneurship research in emergence: past trends and future directions, Journal of Management, 29(3): 285-308.

Casson, M. 2005 The individual-opportunity nexus: a review of Scott Shane: A general theory of entrepreneurship, Small Business Economics, 24(5):423-430. 
Chell, E. 2000 Towards researching the "opportunistic entrepreneur": a social constructionist approach and research agenda, European Journal of work and Organizational Psychology, 9(1): 63-80.

Chiasson, M. and Saunders, Chad 2005 Reconciling diverse approaches to opportunity research using structuration theory, Journal of Business Venturing, 20(6):747-767.

Curran, J. and Blackburn, R.A. 2001 Researcher the Small Enterprise, London: Sage;

Czarniawska, B. 2003 Social constructionism and organization studies in R. Westwood, S. Clegg (eds) Debating organization point-counterpoint in organization studies (Oxford: Blackwell).

Czarniawska, B. and Joerges, B. 1996 Travel of ideas in B. Czarniawska and G. Sevón Translating organizational change (Berlin: de Gruyter).

Czarniawska, B. and G. Sevón 1996 Translating organizational change (Berlin: de Gruyter).

Czarniawska-Joerges, B. 1992 Exploring complex organisations: a cultural perspective Newbury Park, CA:Sage.

Dachler, H.P., Hosking, D.M. and Gergen, K.J. 1995 Relational alternatives to individualisation: management and organisation (Aershot:Avebury)

Davidsson, P. and Wiklund, J. 2001 Levels of analysis in entrepreneurship research: current research practice and suggestions for the future, Entrepreneurship Theory and Practice, 25(4): 81-97.

Denzin, N.K. 1997 Interpretive ethnography: ethnographic practices for the 21st century (Thousand Oaks, CA: Sage).

Dodd, S.D. 2002 Metaphors and meaning: a grounded cultural model of US entrepreneurship, Journal of Business Venturing, 17(5): 519-535.

Downing, S. 2005 The Social construction of entrepreneurship, Entrepreneurship: Theory and Practice, 29(2):185-204.

Du Gay. P. 1996 Consumption and identity at work (London: Sage).

Durkheim, E. 1982 (originally 1895) Rules of sociological method (London: Macmillan).

Earl, P.E. 2003 The entrepreneur as a constructor of connections, Advances in Austrian economics, 6:113-130.

Eckhardt, Jonathan T. and Shane, Scott 2003 Opportunities and Entrepreneurship, Journal of Management, 29(3):333-349.

Entrepreneurship Theory and Practice Special Issue, Vol. 24(4): 2001.

Fischer, E., Reuber, A.R., Hababou, Moez, Johnson, W. and Lee, S. 1997 The role of socially constructed temporal perspectives in the emergence of rapid growth firms, Entrepreneurship Theory and Practice 22(2):13-18. 
Fletcher, D.E. 2003 Framing organisational emergence: discourse, identity and relationship in C. Steyaert, and D. Hjorth, D. (ed.) New Movements in Entrepreneurship (Glos:Cheltenham/MA:Northampton: Edward Elgar).

Fletcher, D.E. 2007 (under review) 'Toy Story': the narrative world of entrepreneurship and the creation of interpretive communities, Journal of Business Venturing.

Fletcher, D.E. and Watson, T.J. 2005 (forthcoming) Entrepreneurship, management learning and negotiated narratives, Management Learning.

Gartner, W.B. 1990 What are we talking about when we talk about entrepreneurship, Journal of Business Venturing 5: 15-28.

Gartner, W.B. 1993 Words lead to deeds: towards an organisational emergence vocabulary, Journal of Business Venturing 8: 231-239.

Gartner, W.B., Carter, N.M and Hills, G.E. 2003 The language of opportunity in C. Steyaert, and D. Hjorth (eds) New Movements in Entrepreneurship (Glos:Cheltenham/MA:Northampton: Edward Elgar).

Gergen, K.K., \& Gergen, M.M. 1991 Toward reflexive methodolgies. In Steier, F. (Ed.), 1992. Research and Reflexivity (London: Sage).

Gergen, K.K. 1999 An invitation to social construction (London: Sage).

Giddens, A. 1979 Central problems in social theory London: Macmillan.

Giddens, A. 1994 Elements of the theory of structuration in The Polity Reader in Social Theory, Cambridge: Polity Press.

Goffman, E. 1972 Encounters: Two Studies in the Sociology of Interaction, (Harmondsmith: Penquin University Books).

Goss, D. 2005 Schumpeter's legacy? Interaction and emotions in the sociology of entrepreneurship, Entreprenership: Theory and Practice,

Grant, P. and Perren, L. 2002 Small business and entrepreneurial research: metatheories, paradigms and prejudices, International Small Business Journal, 20(2): 185-209.

Hacking, I. 1999 The social construction of what? (Cambridge, Mass:Harvard University Press).

Hall, S. (ed) 1997 Representation: culture representation and signifying practices (London:Sage/Open University).

Harrison, R. T. and Leitch, C. M. 1996 Discipline emergence in entrepreneurship: accumulative fragmentalism or paradigmatic science? Entrepreneurship, Innovation and Change, 5: 65-83.

Hashemi, S. and Hashemi, B. 2002 'Anyone can do It': building Coffee Republic from our kitchen table (Chichester, West Sussex: Capstone Publishing).

Hill, R. and Levenhagen, M. 1995 Metaphors and mental models: sensemaking and sense giving in innovative entrepreneurial activities, Journal of Management, 21(6): 1057. 
Hjorth, D. and Johannisson, B. 2003 Conceptualising the opening phase of regional development as the enactment of a 'collective identity', Concepts and Transformations, 8:1:69-92.

Hjorth, Daniel and Steyaert, Chris (eds.) 2004, Narrative and Discursive Approaches in Entrepreneurship Studies (Cheltenham: Edward Elgar).

Hosking, D.M. \& Bass, A. 2001 Constructing changes in relational processes: introducing a social constructionist approach to change work, Career Development Journal, 6(7): 348-360.

Hosking, D. M. and Hjorth, D. 2004, "Relational constructionism and entrepreneurship: some key notes”, in Hjorth, Daniel and Steyaert, Chris (eds.) Narrative and Discursive Approaches in Entrepreneurship Studies, Cheltenham: Edward Elgar

Jack, S. L. and Anderson, A.R. 2002 The effects of embeddedness on the entrepreneurial process, Journal of Business Venturing, 17(5): 467-487.

Johannisson, B. 1990 Community Entrepreneurship - cases and conceptuaisation, Entrepreneurship and Regional Development, 2:71-88.

Johannisson, B. 2002, 'Enacting entrepreneurship using auto-ethnography to study organization creation', Ethnographic Organizational Studies, University of St Gallen, Switzerland, Sept.19-21.

Journal of Business Venturing, 1999. Seminar on research perspectives in entrepreneurship (1997).

Journal of Management Special Issue, Vol 29(3), 2003.

Katz, J. and Steyaert, C. 2004 'Reclaiming the space of entrepreneurship in society: geographical, discursive and social dimensions', Entrepreneurship and Regional Development, 16(3): 179-196.

Kelemen, M. and Hassard, J. 2003 Paradigm plurality: examining past, present and future trends in R. Westwood, S. Clegg (eds) Debating Organization Point-counterpoint in organization studies (Oxford: Blackwell).

Knights, D. and Willmott, H. 1999 Management lives: power and identity in work organisations, London:Sage.

Kupferberg, F. 1998 Humanistic entrepreneurship and entrepreneurial career commitment, Entrepreneurship and Regional Development, 10:171-188.

Lee, J.H. and Venkataraman, S. 2006 Aspirations, market offerings, and the pursuit of entrepreneurial opportunities, Journal of Business Venturing, 21(1):107-123.

Lumpkin, G.T., Hills, G.E. and Strader, R.C. 2003 Opportunity recognition in H.P. Welsch (ed) Entrepreneurship: the way ahead, New York: Routledge.

Lumpkin, G.T. and Lichtenstein, B.B. 2005 The role of organisational learning in the opportunity-recognition process, Entrepreneurship: Theory and Practice, 29(4):451-472.

Manimala, M.J. 1992 Entrepreneurial heuristics: a comparison between high pioneeringinnovative (PI) and low PI ventures, Journal of Business Venturing, 7: 477-504. 
Mead, G.H. 1934 Mind Self and Society (Chicago:University of Chicago press).

Mumby-Croft. R. and Hackely, C.E. 1997 The social construction of market entrepreneurship: a case analysis in the UK fishing industry, Marketing Education Review, 7(3): 87-94.

Nodoushani, O. and Nodoushani, P.A. 1999 A deconstructionist theory of entrepreneurship, American Business Review, 17(1): 45-49.

O’Connor, E. 2002 Storied business: typology, intertextuality, and traffic in entrepreneurial narrative, The Journal of Business Communication, 29(1), 36-54.

Ogbor, J.O. 2000 Mythicising and reification in entrepreneurial discourse: ideologycritique of entrepreneurial studies, Journal of Management Studies, 37(5): 605-635.

Olson, M. in S.D. Sarasvathy 1997 Seminar on research perspectives in entrepreneurship, Journal of Business Venturing, 15: 1-57.

Pitt, M. 1998 A tale of two gladiators: 'reading' entrepreneurs as texts, Organisation Studies 19(3):387-414.

Rae, D. 2002 'Entrepreneurial emergence: a narrative study of entrepreneurial learning in independently owned media businesses', International Journal of Entrepreneurship and Innovation, 3(1):53-59.

Schutz, A. 1967 The phenomenology of the social world (Evanston, IL: Northwestern University Press).

Shane, S. 2000 Prior knowledge and the discovery of entrepreneurial opportunities, Organization Science, 2, 448-469.

Shane, S. 2003 A general theory of entrepreneurship: the individual-opportunity nexus (Northampton, MASS, Edward Elgar.

Shane, S. and Venkataraman, S. 2000 The promise of entrepreneurship as a field of research, Academy of Management Review, 25(1): 217-226.

Stewart, A. 1991 A prospectus on the anthropology of entrepreneurship, Entrepreneurship Theory \& Practice, 16(2): 71-92.

Steyaert, C. 1998 A qualitative methodology for process studies of entrepreneurship, International Studies of Management and Organisation, 27(3): 13-33.

Steyaert, C. and Hjorth, D. (eds), 2003 New Movements in Entrepreneurship (Glos:Cheltenham/MA:Northampton: Edward Elgar).

Turner, J. 1990 The misuse and use of metatheory, Sociological Forum, 5(1):

Ucbasaran, D., Westhead, P. and Wright, M. 2001 The focus of entrepreneurial research: contextual and process issues, Entrepreneurship Theory and Practice, 25(4): 57-80 
Von Glasersfeld, E 1974 Piaget and the radical constructivist epistemology, in C.D. Smock \& E. von Glasersfeld (eds), Epistemology and Education, (Athens, GA: Follow Through Publications).

Von Glasersfeld, E. 1991 Knowing without Metaphysics: aspects of the radical constructivist position. In F. Steier (ed), Research and Reflexivity (London: Sage).

Warren L. 2004 Negotiating entrepreneurial identity - Communities of practice and changing discourses, The International Journal of Entrepreneurship and Innovation, 5, 1: 25-35.

Weber, M. 1978 Economy and Society (Berkeley, CA:University of California Press).

Vygotsky, L. 1981 The genesis of higher mental functions in J.V. Wertsch (ed) The concept of activity in Soviet psychology (Amronk, NY:M.W. Sharpe).

Zafirovski, M. 1999 Probing into the social layers of entrepreneurship outlines of the sociology of enterprise, Entrepreneurship and Regional Development, 11(4):351-372. 
